\title{
Komposisi Asam Lemak dan Kadar Malondialdehida Daging Itik Lokal yang diberi Antioksidan Alami
}

\author{
Composition of Fatty Acid and Malondialdehyde Levels in Local Duck Meat as Natural Antioxidant \\ Source
}

\author{
D. Lestari ${ }^{1 *}$, Rukmiasih ${ }^{2}$, T. Suryati ${ }^{2}$ P. S. Hardjosworo ${ }^{2}$, \& J. A. Lase ${ }^{3}$ \\ ${ }^{1}$ Fakultas Pertanian dan Peternakan Universitas Muhammadiyah Kotabumi \\ ${ }^{2}$ Departemen Ilmu Produksi dan Teknologi Peternakan, Fakultas Peternakan, IPB University \\ ${ }^{3}$ Balai Pengkajian Teknologi Pertanian (BPTP) Maluku Utara \\ *Corresponding author: dianlestari785@gmail.com \\ (Received 05-06-2020; Revised 08-08-2020; Accepted 27-08-2020)
}

\begin{abstract}
Cihateup duck is one of the local Indonesian poultry from West Java. These ducks are raised in Tasikmalaya and Garut. Cihateup duck has the potential to produce meat, but duck meat has been considered to have off-odor. components off-odor formed when the fatty acids are oxidized. A study with the aim to protect unsaturated fatty acids in local duck meat from oxidation using Pluchea indica Less (beluntas) and Cosmos caudatus (kenikir) in feed as the source of natural antioxidants. The study used was complete randomized design (RAL) with 7 treatments and 5 replications. The treatment was Pluchea indica Less or Cosmos caudatus powder with the duration of administration 1, 2 or 3 weeks before the age of harvest (10 weeks). Ducks used were 35 heads of Cihateup duck. Variables observed were moisture content, fat content, Malondialdehyde (MDA), composition of fatty acid, and sensory characteristic of duck meat. The results showed that the effect of Pluchea indica Less or Cosmos caudatus were not significant on moisture content and fat content. The effect of Pluchea indica Less or Cosmos caudatus on MDA, composition of fatty acid, and and off-odor intensities of duck meat during cooking was significantly different $(\mathrm{P}<\mathbf{0 . 0 5})$. It was concluded that this addition of Pluchea indica Less for 3 weeks or Cosmos caudatus for 2 weeks could lower off-odor on local duck meat.
\end{abstract}

Keywords: Composition of fatty acid, Cosmos caudatus (kenikir), Malondialdehyde, Pluchea indica Less (beluntas)

\section{ABSTRAK}

Itik Cihateup merupakan ternak rakyat yang berasal dari Jawa Barat dan banyak dikembangkan di daerah Tasikmalaya dan Garut. Itik Cihateup berpotensi sebagai penghasil daging tetapi dagingnya memiliki bau tak sedap. Komponen bau tidak sedap terbentuk saat asam lemak teroksidasi. Penelitian ini bertujuan untuk melindungi komponen asam lemak tak jenuh pada daging itik lokal dari oksidasi dengan menggunakan Pluchea indica Less (beluntas) dan Cosmos caudatus (kenikir) sebagai sumber antioksidan alami. Penelitian ini menggunakan rancangan acak lengkap (RAL) dengan 7 perlakuan dan 5 ulangan. Perlakuan yang diberikan adalah penambahan tepung Pluchea indica Less atau Cosmos caudatus dengan durasi pemberian 1, 2 atau 3 minggu sebelum panen (10 minggu). Itik yang digunakan adalah itik Cihateup sebanyak 35 ekor. Variabel yang diamati adalah kadar air, kadar lemak, kadar malondialdehid (MDA), komposisi asam lemak, dan uji hedonik daging. Hasil penelitian menunjukkan bahwa pemberian tepung Pluchea indica Less atau Cosmos caudatus tidak berpengaruh terhadap kadar air dan kadar lemak. Namun pemberian Pluchea indica Less atau Cosmos caudatus berpengaruh nyata $(\mathrm{P}<\mathbf{0 , 0 5})$ pada kadar MDA, komposisi asam lemak, dan tingkat kesukaan bau pada daging matang. Disimpulkan bahwa pemberian beluntas selama 3 minggu atau kenikir selama 2 minggu dapat melindungi asam lemak tidak jenuh dari oksidasi, pembentukan MDA, dan meningkatkan penerimaan bau daging itik.

Kata Kunci: Cosmos caudatus (kenikir), Komposisi Asam Lemak, Malondialdehida, Pluchea indica Less (beluntas) 


\section{PENDAHULUAN}

Itik Cihateup merupakan ternak rakyat yang berasal dari Jawa Barat dan banyak dikembangkan di daerah Tasikmalaya dan Garut (Wulandari et al. 2005). Itik Cihateup memiliki ukuran tubuh yang lebih besar dibandingkan itik Cirebon dan Mojosari (Muzani et al. 2005). Sumber daging unggas secara nasional masih didominasi oleh ayam ras pedaging. Berdasarkan data Ditjen PKH (2019), produksi daging ayam ras pedaging yaitu 3,495,091 ton, sedangkan produksi daging itik yaitu 36,346 ton.

Saat ini telah banyak upaya untuk menunjang program ketahanan pangan di Indonesia, salah satunya dengan meningkatkan konsumsi protein hewani. Untuk memperkaya keragaman protein hewani, itik banyak dimanfaatkan sebagai penghasil telur dan daging (Matitaputty \& Suryana 2014), namun konsumsi daging itik masih rendah dibandingkan dengan konsumsi daging ayam ras. Konsumsi daging itik pada tahun 2017 yaitu $0.052 \mathrm{~kg}$ per kapita (Ditjen PKH 2019). Kendala yang menyebabkan rendahnya konsumsi daging itik, yaitu karakteristik daging itik yang amis (Matitaputty 2012) dan memiliki kadar lemak lebih tinggi dari ayam ras pedaging (Kim et al. 2009b).

Upaya yang banyak dilakukan untuk menutupi flavor khas daging itik yang amis yaitu dengan mengolah daging menggunakan berbagai jenis bumbu. Akan tetapi, bumbu-bumbu tersebut masih belum bisa menutupi flavor khas daging itik. Salah satu penyebab bau amis pada daging itik, yaitu karena terjadinya oksidasi lipida (Juntachote et al. 2007). Proses oksidasi pada daging melibatkan asam lemak di dalam daging itik (Sacchetti et al. 2008). Selain karakteristik daging yang amis, daging itik juga memiliki warna yang lebih merah. Warna merah tersebut disebabkan oleh tingginya kandungan hemoglobin dan mioglobin yang mengakibatkan tingginya kandungan Fe dalam daging. Ion Fe tersebut merupakan katalis oksidasi (Yoon et al. 2010). Indikasi oksidasi dapat diketahui melalui pengukuran kadar lemak, komposisi asam lemak, dan kadar MDA yang terbentuk.

Upaya lain yang dilakukan untuk mengurangi bau amis pada daging itik, yaitu dengan memanfaatkan pakan aditif sebagai sumber antioksidan. Pakan aditif yang ditambahkan ke dalam pakan dapat berupa vitamin atau tanaman herbal (Lestari et al. 2017). Pakan aditif sebagai sumber antioksidan dapat berperan dalam penghambatan proses oksidasi dengan cara pemberian atom hidrogen pada senyawa yang tidak stabil menjadi lebih stabil (Tamat et al. 2007). Sumber antioksidan dapat dikelompokkan menjadi dua, yaitu: antioksidan sintetis dan alami. Pemanfaatan antioksidan sintetis mulai mengalami penurunan karena dikhawatirkan dapat berdampak pada kesehatan (Valentao et al. 2010), sedangkan antioksidan yang berasal dari alam memiliki kandungan yang jarang menyebabkan residu sehingga aman dikonsumsi. Tanaman yang mengandung antioksidan alami antara lain beluntas dan kenikir. Beluntas mengandung senyawa fenolik sebesar $0.83 \pm 0.13 \mathrm{mg}$ GAE/g BK dan kenikir mengandung senyawa fenolik sebesar $1.52 \pm 0.11 \mathrm{mg} \mathrm{GAE} / \mathrm{g}$ BK (Andarwulan et al. 2010). Senyawa fenolik merupakan senyawa utama yang memiliki peranan sebagai antioksidan (Zhao et al. 2007). Menurut Rukmiasih (2011), penggunaan beluntas sebanyak 1\% selama 3, 5 dan 7 minggu mempunyai pengaruh yang sama dalam mengurangi bau amis daging itik. Namun, efektifitas kenikir sebagai antioksidan dan lama pemberian beluntas kurang dari 3 minggu untuk menurunkan off-flavor daging belum banyak diketahui. Berdasarkan hal tersebut maka dilakukan penelitian untuk menurunkan off-flavor pada daging itik dengan menggunakan beluntas dan kenikir $1 \%$ selama 1, 2 atau 3 minggu.

\section{METODE}

Penelitian dilaksanakan di Laboratorium Lapang IPB, Laboratorium Terpadu Departemen Ilmu Produksi dan Teknologi Peternakan IPB (IPTP), dan Laboratorium Kimia Terpadu IPB. Penelitian ini menggunakan 35 ekor itik Cihateup jantan yang terdiri atas 7 perlakuan dengan 5 ulangan. Pelaksanaan penelitian dilakukan dalam 2 tahap, yaitu: pembuatan tepung daun dan penerapan perlakuan pada ternak.

\section{Tahap 1 : Pembuatan dan Analisis Tepung Daun Beluntas serta Kenikir}

Daun beluntas atau kenikir $( \pm 20 \mathrm{~cm}$ dari pucuk tanaman) dijemur di bawah matahari $( \pm 3$ jam $)$, kemudian dikeringkan dalam oven $55{ }^{\circ} \mathrm{C}( \pm 3$ jam) sebelum digiling menggunakan blender. Daun beluntas atau kenikir yang sudah dalam bentuk tepung dianalisis kandungan fenolik, kapasitas antioksidan, aktivitas antioksidan, dan tanin. Metode analisis fenolik mengacu pada metode Conforti et al. (2006). Total fenolik dinyatakan sebagai ekuivalen asam galat atau gallic acid equivalent (GAE). Warna biru yang terbentuk pada larutan diukur absorbansinya menggunakan spekrofotometer (Agilent 8453 UVVisible spectrophotometer, US) yang dibaca pada panjang gelombang $765 \mathrm{~nm}$. Pengujian aktivitas antioksidan dalam penghambatan DPPH (2.2-diphenyl-1-picrylhydrazyl) diketahui dengan adanya perubahan warna pada larutan DPPH dalam metanol yang semula berwarna ungu pekat menjadi kuning pucat (Permana et al. 2003), dan dinyatakan sebagai mg ekuivalen vitamin C $100 \mathrm{~g}^{-1}$ atau AEAC (Ascorbic Acid Equivalent Antioxidant Capacity). Pengujian aktivitas dan kapasitas antioksidan diukur dengan metode analisis Tangkanakul (2009), sedangkan kandungan tanin ditentukan dengan metode Chanwitheesuk et al. (2005) yang dimodifikasi dan absorbansi dibaca pada panjang gelombang $760 \mathrm{~nm}$. Kandungan total tanin dinyatakan dalam persen.

\section{Tahap 2: Penerapan Perlakuan pada Ternak}

Pemberian perlakuan pada ternak dilakukan pada umur 7 minggu sampai 10 minggu yang terdiri atas: Kontrol = Pakan komersial sampai dipotong (10 minggu); $\mathrm{B} 1=$ Tepung daun beluntas $1 \%$ selama 1 minggu sebelum dipotong (10 minggu);

B2= Tepung daun beluntas $1 \%$ selama 2 minggu sebelum dipotong (10 minggu);

B3= Tepung daun beluntas $1 \%$ selama 3 minggu sebelum dipotong (10 minggu); 
$\mathrm{K} 1=$ Tepung daun kenikir $1 \%$ selama 1 minggu sebelum dipotong (10 minggu);

$\mathrm{K} 2=$ Tepung daun kenikir 1\% selama 2 minggu sebelum dipotong (10 minggu);

$\mathrm{K} 3=$ Tepung daun kenikir $1 \%$ selama 3 minggu sebelum dipotong (10 minggu).

Jumlah pemberian pakan mengacu kepada Sinurat (2000), kebutuhan pakan itik pada umur 7-8 minggu sebanyak $120 \mathrm{~g} /$ ekor/hari, umur 8-9 minggu sebanyak 130 g/ekor/hari, dan umur 9-10 minggu sebanyak 145 g/ekor/ hari.

\section{Pengukuran Peubah}

Peubah yang diukur pada penelitian ini terdiri atas : konsumsi senyawa fenolik, konsumsi tanin,kadar air, kadar lemak, kadar MDA, komposisi asam lemak, dan uji hedonik. Konsumsi fenolik dan tanin diperoleh dengan cara menghitung jumlah konsumsi beluntas atau kenikir dikalikan dengan kandungan fenolik atau tanin dari masingmasing tepung daun beluntas atau kenikir.

Metode analisis kadar air dan kadar lemak mengacu pada metode AOAC (1984), sedangkan penentuan kadar MDA dilakukan dengan mengacu pada metode Sorensen \& Jorgensen (1996) yakni mengukur absorbansi sampel menggunakan spekrofotometer UV-Vis $(\lambda=528 \mathrm{~nm})$ dan senyawa tetraetoksipropana sebagai standar.

Komposisi asam lemak daging pahadiperoleh dengan cara mengekstraksi daging dan ditransformasi ke dalam bentuk ester dengan cara metilasi sehingga diperoleh metil ester asam lemak (FAME), kemudian dianalisis dengan kromatografi gas (AOAC 2005). Uji hedonik dilakukan dengan menggunakan sampel daging bagian paha dalam kondisi mentah dan matang. Pengujian dilakukan oleh 80 orang panelis tidak terlatih. Panelis diminta untuk memberi nilai tingkat kesukaan pada bau, warna, dan tekstur daging itik yang telah diberi perlakuan. Skala hedonik yang digunakan berkisar dari satu sampai lima yaitu: 1 = sangat tidak suka; $2=$ tidak suka; $3=$ agak suka; $4=$ suka; $5=$ sangat suka.

\section{Analisis Data}

Data konsumsi fenolik, konsumsi tanin, kadar air, kadar lemak, kadar MDA, dan komposisi asam lemak dianalisis dengan analisis ragam menggunakan rancangan acak lengkap (RAL) dan apabila diperoleh hasil yang berbeda dilanjutkan dengan uji Duncan Multiple Range Test (DMRT) (Steel \& Torrie 1995). Data hasil uji hedonik dianalisis secara nonparametrik dengan uji Kruskal-Wallis dan dilakukan uji Mann-Whitney pada data yang menunjukkan hasil berbeda nyata. Pengolahan data dilakukan dengan menggunakan program SPSS for windows versi 18.

\section{HASIL DAN PEMBAHASAN}

\section{Kandungan Antioksidan pada Tepung Daun Beluntas dan Kenikir}

Senyawa antioksidan yang meliputi total tanin, total fenolik, dan aktivitas serta kapasitas antioksidan pada tepung daun beluntas atau kenikir disajikan pada
Tabel 1. Pada penelitian ini daun beluntas atau kenikir yang digunakan yakni $\pm 20 \mathrm{~cm}$ dari pucuk tanaman. Hasil analisis menunjukkan bahwa daun beluntas atau kenikir mengandung total fenolik sebesar $1.04 \pm 0.05 \mathrm{mg}$ GAE/g BK dan daun kenikir mengandung total fenolik sebesar $1.22 \pm 0.10 \mathrm{mg}$ GAE/g BK. Hasil ini menunjukkan bahwa total fenolik daun beluntas lebih tinggi dibandingkan dengan hasil penelitian Andarwulan et al. (2010) yang menggunakan daun $\pm 50 \mathrm{~cm}$ dari pucuk tanaman. Hal ini diduga karena jumlah daun dari pucuk tanaman yang digunakan berbeda sehingga mempengaruhi kadar fenolik daun beluntas.

Tabel 1. Senyawa antioksidan tepung daun beluntas dan kenikir

\begin{tabular}{lcc}
\hline Parmeter & \multicolumn{2}{c}{ Tepung Daun } \\
\cline { 2 - 3 } & Beluntas & Kenikir \\
\hline Total Tanin $(\% / 100 \mathrm{~g} \mathrm{BK})$ & 1.12 & 1.28 \\
$\begin{array}{l}\text { Total Fenolik } \\
(\mathrm{mg} \text { GAE/g BK) }\end{array}$ & $1.04 \pm 0.05$ & $1.22 \pm 0.10$ \\
$\begin{array}{l}\text { Kapasitas Antioksidan } \\
(\text { mg AEAC/100 g-1) }\end{array}$ & $27.79 \pm 2.78$ & $48.13 \pm 2.62$ \\
$\begin{array}{l}\text { Aktivitas Antioksidan/ } \\
\text { Scavenging Activity }(\%)\end{array}$ & $14.40 \pm 2.20$ & $24.73 \pm 1.63$ \\
\hline
\end{tabular}

Menurut Paini (2011), daun beluntas yang lebih muda memiliki konsentrasi fenolik lebih tinggi. Pernyataan tersebut diperkuat oleh Navarro et al. (2006), perbedaan kadar senyawa fenolik pada daun sangat dipengaruhi oleh tingkat ketuaan dari daun tersebut. Pada hasil analisis senyawa fenolik daun kenikir menunjukkan angka lebih rendah dibandingkan dengan hasil analisis Andarwulan et al. (2010) yakni $1.52 \pm 0.11 \mathrm{mg}$ GAE/g BK. Kondisi ini diduga karena perbedaan wilayah sehingga kesuburan dan nutrisi yang diserap oleh tanaman berbeda. Kesuburan tanah yang berbeda akan menyediakan unsur hara essensial yang berbeda untuk tanaman.

Kandungan senyawa antioksidan pada kenikir secara deskriptif lebih tinggi dibandingkan dengan beluntas. Kondisi ini sejalan dengan Andarwulan et al. (2010) yang melaporkan bahwa kenikir mengandung fenolik lebih tinggi dibandingkan dengan beluntas. Menurut Nurjanah et al. (2011), semakin tinggi nilai fenolik maka semakin tinggi kemampuan antioksidan dalam mendonorkan elektronnya sehingga menekan perkembangan radikal bebas.

Kandungan tanin pada tepung daun kenikir juga lebih tinggi dibandingkan dengan beluntas. Menurut Zhao et al. (2007), tanin merupakan bagian dari senyawa fenolik yang berasal dari tanaman sehingga dapat berperan sebagai antioksidan. Hasil ini menunjukkan bahwa kenikir mengandung antioksidan lebih banyak dibandingkan dengan beluntas sehingga kemampuan dan kekuatan menghambat radikal lebih baik.

\section{Pengaruh Tepung Daun Beluntas atau Kenikir terhadap Kimia Daging}

Berdasarkan total konsumsi fenolik dan tanin, itik yang diberi kenikir mendapat senyawa fenolik dan tanin lebih banyak dibandingkan dengan itik yang diberi beluntas 
sehingga asupan antioksidannya lebih tinggi (Tabel 2). Konsumsi antioksidan yang lebih tinggi pada kenikir tidak menunjukkan pengaruh yang nyata pada kadar lemak dan kadar air (Tabel 3). Kadar lemak lebih banyak dipengaruhi oleh kandungan nutrisi pakan. Pada penelitian ini kandungan nutrisi pakan yang digunakan sama sehingga diduga proses lipogenesis (pembentukan lemak) pada itik sama. Lemak merupakan salah satu komponen yang dapat menentukan flavor daging yang dihasilkan. Daging yang mengandung lemak tinggi akan meningkatkan potensi oksidasi.
Indikasi kerusakan daging akibat oksidasi dapat diketahui melalui kadar MDA pada daging itik. Kadar MDA nyata lebih rendah $(\mathrm{P}<0.05)$ pada perlakuan $\mathrm{B} 3, \mathrm{~K} 2$, dan $\mathrm{K} 3$ (Tabel 3). Hal ini diduga karena pada perlakuan tersebut itik mengkonsumsi kandungan antioksidan lebih tinggi. Hasil ini memperlihatkan bahwa oksidasi dapat dipengaruhi oleh aktivitas antioksidan yang terkandung didalam beluntas atau kenikir. Menurut Rababah (2006), antioksidan mampu menurunkan kadar MDA pada daging mentah dan matang.

Tabel 2. Rata-rata konsumsi senyawa fenolik dan tanin yang terkandung didalam tepung

\begin{tabular}{|c|c|c|c|c|c|c|}
\hline \multirow[t]{3}{*}{ Perlakuan } & \multicolumn{4}{|c|}{ Konsumsi Tepung Daun } & \multirow{3}{*}{$\begin{array}{c}\text { *Konsumsi } \\
\text { Fenolik dari } \\
\text { 7-10 Minggu } \\
\text { (mg/ekor) }\end{array}$} & \multirow{3}{*}{$\begin{array}{c}\text { *Konsumsi } \\
\text { Tanin dari } \\
\text { 7-10 Minggu } \\
\text { (\%/ekor) }\end{array}$} \\
\hline & 7-8 Minggu & 8-9 Minggu & 9-10 Minggu & Total (7-10 Minggu) & & \\
\hline & \multicolumn{4}{|c|}{------------------(g/ekor)------------------ } & & \\
\hline Kontrol & 0 & 0 & 0 & 0 & 0 & 0 \\
\hline B1 & 0 & 0 & $10.45 \pm 0.01$ & $10.45 \pm 0.01$ & $10.87 \pm 0.01$ & $0.12 \pm 0.00$ \\
\hline B2 & 0 & $9.03 \pm 0.01$ & $10.45 \pm 0.01$ & $19.47 \pm 0.01$ & $20.25 \pm 0.01$ & $0.22 \pm 0.00$ \\
\hline B3 & $8.89 \pm 0.02$ & $9.03 \pm 0.01$ & $10.45 \pm 0.01$ & $28.37 \pm 0.01$ & $29.50 \pm 0.01$ & $0.32 \pm 0.00$ \\
\hline K1 & 0 & 0 & $10.45 \pm 0.01$ & $10.45 \pm 0.01$ & $12.75 \pm 0.01$ & $0.13 \pm 0.00$ \\
\hline K2 & 0 & $9.03 \pm 0.01$ & $10.45 \pm 0.01$ & $19.48 \pm 0.01$ & $23.76 \pm 0.01$ & $0.25 \pm 0.00$ \\
\hline K3 & $8.88 \pm 0.02$ & $9.03 \pm 0.01$ & $10.45 \pm 0.01$ & $28.36 \pm 0.02$ & $34.60 \pm 0.03$ & $0.36 \pm 0.00$ \\
\hline
\end{tabular}

*Hasil perhitungan berdasarkan kandungan senyawa aktif; B1: beluntas 1 minggu; B2:beluntas 2 minggu; B3:beluntas 3 minggu; K1:kenikir 1 minggu; K2:kenikir 2 minggu; K3:kenikir 3 minggu

Oksidasi lemak merupakan tanda daging mulai mengalami penurunan kualitas dan dapat menimbulkan off-flavor (Purba 2014). Oksidasi juga dapat dipengaruhi oleh kandungan air pada daging. Menurut Sudarmadji (2003), bahan yang mempunyai kandungan air tinggi akan cepat mengalami kerusakan akibat pertumbuhan mikroba pembusuk maupun akibat terjadinya reaksi kimia tertentu, seperti oksidasi dan reaksi enzimatik.

Tabel 3. Pengaruh tepung daun beluntas atau kenikir terhadap sifat kimia daging

\begin{tabular}{lccc}
\hline Perlakuan & $* *$ Kadar Lemak $*$ Kadar Air & $\begin{array}{c}* \text { MDA } \\
(\mathrm{mg} / \mathrm{kg})\end{array}$ \\
\hline Kontrol & $------------(\%)---------$ & $0.52 \pm 0.17 \mathrm{a}$ \\
B1 & $28.89 \pm 1.93$ & $71.74 \pm 3.00$ & $0.52 \pm 0.08 \mathrm{a}$ \\
B2 & $28.53 \pm 2.62$ & $71.30 \pm 3.04$ & $0.51 \pm 0.05 \mathrm{a}$ \\
B3 & $28.03 \pm 4.00$ & $71.15 \pm 2.48$ & $0.30 \pm 0.15 \mathrm{~b}$ \\
K1 & $28.05 \pm 1.65$ & $71.94 \pm 4.49$ & $0.51 \pm 0.23 \mathrm{a}$ \\
K2 & $28.03 \pm 2.16$ & $71.13 \pm 2.46$ & $0.31 \pm 0.09 \mathrm{~b}$ \\
K3 & $27.92 \pm 1.38$ & $71.53 \pm 3.71$ & $0.21 \pm 0.10 \mathrm{~b}$ \\
\hline
\end{tabular}

*Hasil analisis laboratorium ilmu produksi dan teknologi peternakan IPB; **Hasil analisis laboratorium kimia terpadu IPB; B1: beluntas 1 minggu; B2:beluntas 2 minggu; B3:beluntas 3 minggu; K1:kenikir 1 minggu; K2:kenikir 2 minggu; K3:kenikir 3 minggu; angka yang disertai dengan huruf yang berbeda pada kolom yang sama menunjukkan berbeda nyata $(\mathrm{P}<0.05)$.
Pada lama pemberian yang sama, kadar MDA pada daging itik yang mendapat kenikir lebih rendah dibandingkan dengan itik yang mendapat beluntas. Hal ini diduga karena kandungan antioksidan pada kenikir lebih tinggi dibandingkan dengan beluntas sehingga kemampuan dalam menghambat reaksi oksidasi lebih cepat. Menurut Rukmiasih (2011), semakin tinggi level pemberian antioksidan maka semakin rendah kadar MDA.

\section{Efektivitas Tepung Daun Beluntas atau Kenikir terhadap Komposisi Asam Lemak Daging}

Komposisi asam lemak yang mengalami perubahan akibat pemberian tepung daun beluntas atau kenikir antara lain asam lemak jenuh (ALJ) yakni asam palmitat (C16:0) dan asam arasidat (C20:0); asam lemak tidak jenuh tunggal (ALTJT) yakni asam oleat (C18:1); dan asam lemak tidak jenuh ganda (ALTJG) yakni asam linoleat (C18:2), asam linolenat (C18:3), cis-8, 11, 14-asam eicosedienoat (C20:3), dan asam arachidonat (C20:4) yang disajikan pada Tabel 4.

ALTJ merupakan golongan asam lemak esensial yang ada pada daging itik. Total ALTJ pada perlakuan pemberian beluntas atau kenikir nyata lebih tinggi dibandingkan dengan kontrol. Hasil ini menunjukkan bahwa aktivitas antioksidan yang ada pada beluntas atau kenikir dapat melindungi ALTJ dari oksidasi. Mekanisme antioksidan dalam melindungi asam lemak diduga dengan cara pemberian atom hidrogen, menangkap radikal bebas, atau dengan menghambat kerja enzim prooksidan (Tamat et al. (2007). 
Lestari et al.

Jurnal Ilmu Produksi dan Teknologi Hasil Peternakan 8 (3): 117-123

Tabel 4. Komposisi asam lemak pada daging itik yang diberi tepung daun beluntas atau kenikir $1 \%$

\begin{tabular}{|c|c|c|c|c|c|c|c|}
\hline \multirow[t]{2}{*}{ Asam lemak } & \multicolumn{7}{|c|}{ Perlakuan } \\
\hline & Kontrol & \multicolumn{5}{|c|}{ B1 B2 B3 K1 K2 } & K3 \\
\hline \multicolumn{8}{|l|}{ ALJ } \\
\hline $\mathrm{C} 10: 0$ & 0 & $0.01 \pm 0.01$ & 0 & 0 & $0.01 \pm 0.01$ & 0 & $0.01 \pm 0.01$ \\
\hline $\mathrm{C} 12: 0$ & $0.04 \pm 0.01$ & $0.04 \pm 0.01$ & $0.05 \pm 0.01$ & $0.05 \pm 0.01$ & $0.04 \pm 0.00$ & $0.05 \pm 0.02$ & $0.04 \pm 0.01$ \\
\hline $\mathrm{C} 14: 0$ & $0.41 \pm 0.03$ & $0.41 \pm 0.03$ & $0.41 \pm 0.03$ & $0.41 \pm 0.03$ & $0.41 \pm 0.03$ & $0.41 \pm 0.03$ & $0.41 \pm 0.03$ \\
\hline $\mathrm{C} 15: 0$ & $0.05 \pm 0.01$ & $0.05 \pm 0.00$ & $0.05 \pm 0.00$ & $0.05 \pm 0.00$ & $0.05 \pm 0.00$ & $0.05 \pm 0.01$ & $0.05 \pm 0.00$ \\
\hline $\mathrm{C} 16: 0$ & $22.87 \pm 0.60 \mathrm{a}$ & $23.03 \pm 0.56 \mathrm{a}$ & $23.51 \pm 0.74 \mathrm{a}$ & $20.20 \pm 1.78 b$ & $22.21 \pm 1.42 \mathrm{a}$ & $20.28 \pm 1.38 b$ & $20.34 \pm 0.73 b$ \\
\hline $\mathrm{C} 17: 0$ & $0.10 \pm 0.01$ & $0.10 \pm 0.00$ & $0.10 \pm 0.00$ & $0.10 \pm 0.01$ & $0.10 \pm 0.01$ & $0.10 \pm 0.01$ & $0.10 \pm 0.01$ \\
\hline C18:0 & $4.26 \pm 0.61$ & $4.33 \pm 0.74$ & $3.99 \pm 0.49$ & $4.93 \pm 0.61$ & $4.52 \pm 0.40$ & $4.57 \pm 0.19$ & $4.48 \pm 0.71$ \\
\hline $\mathrm{C} 20: 0$ & $0.09 \pm 0.01 \mathrm{~b}$ & $0.10 \pm 0.01 \mathrm{~b}$ & $0.09 \pm 0.01 \mathrm{~b}$ & $0.12 \pm 0.02 \mathrm{a}$ & $0.10 \pm 0.01 \mathrm{~b}$ & $0.10 \pm 0.00 \mathrm{~b}$ & $0.12 \pm 0.01 \mathrm{a}$ \\
\hline $\mathrm{C} 22: 0$ & $0.02 \pm 0.01$ & $0.02 \pm 0.00$ & $0.01 \pm 0.02$ & $0.03 \pm 0.01$ & $0.02 \pm 0.00$ & $0.01 \pm 0.01$ & $0.01 \pm 0.01$ \\
\hline $\mathrm{C} 24: 0$ & 0 & $0.01 \pm 0.01$ & $0.01 \pm 0.01$ & $0.01 \pm 0.01$ & $0.01 \pm 0.01$ & $0.00 \pm 0.01$ & $0.01 \pm 0.01$ \\
\hline TOTAL & $27.84 \pm 1.29 \mathrm{ab}$ & $28.09 \pm 1.36 \mathrm{a}$ & $28.22 \pm 1.29 \mathrm{a}$ & $25.89 \pm 2.48 b c$ & $27.46 \pm 1.88 \mathrm{abc}$ & $25.56 \pm 1.64 \mathrm{c}$ & $25.58 \pm 1.52 \mathrm{c}$ \\
\hline \multicolumn{8}{|l|}{ ALTJT } \\
\hline C14:1 & $0.04 \pm 0.01$ & $0.03 \pm 0.01$ & $0.04 \pm 0.01$ & $0.04 \pm 0.01$ & $0.04 \pm 0.01$ & $0.03 \pm 0.01$ & $0.04 \pm 0.01$ \\
\hline C16:1 & $2.16 \pm 0.43$ & $2.16 \pm 0.43$ & $2.16 \pm 0.43$ & $2.16 \pm 0.43$ & $2.16 \pm 0.43$ & $2.16 \pm 0.43$ & $2.16 \pm 0.43$ \\
\hline $\mathrm{C} 17: 1$ & $0.07 \pm 0.01$ & $0.07 \pm 0.01$ & $0.07 \pm 0.00$ & $0.07 \pm 0.01$ & $0.06 \pm 0.01$ & $0.07 \pm 0.01$ & $0.07 \pm 0.00$ \\
\hline $\mathrm{C} 18: \ln 9 \mathrm{t}$ & $0.15 \pm 0.02$ & $0.15 \pm 0.01$ & $0.14 \pm 0.02$ & $0.15 \pm 0.03$ & $0.15 \pm 0.02$ & $0.15 \pm 0.03$ & $0.22 \pm 0.15$ \\
\hline $\mathrm{C} 18: \ln 9 \mathrm{c}$ & $37.94 \pm 1.57 \mathrm{~b}$ & $40.04 \pm 1.16 \mathrm{ab}$ & $39.52 \pm 1.39 \mathrm{ab}$ & $40.89 \pm 1.71 \mathrm{a}$ & $38.42 \pm 2.46 \mathrm{~b}$ & $41.01 \pm 0.93 \mathrm{a}$ & $41.70 \pm 0.64 \mathrm{a}$ \\
\hline TOTAL & $40.35 \pm 2.03 b$ & $42.45 \pm 1.62 \mathrm{ab}$ & $41.92 \pm 1.85 \mathrm{ab}$ & $43.30 \pm 1.18 \mathrm{a}$ & $40.83 \pm 2.92 b$ & $43.42 \pm 1.41 \mathrm{a}$ & $44.19 \pm 1.24 \mathrm{a}$ \\
\hline \multicolumn{8}{|l|}{ ALTJG } \\
\hline C18:2 & $13.90 \pm 0.10 \mathrm{~b}$ & $13.83 \pm 1.73 b$ & $14.31 \pm 0.36 b$ & $16.30 \pm 1.03 \mathrm{a}$ & $14.36 \pm 0.70 \mathrm{~b}$ & $16.29 \pm 0.72 \mathrm{a}$ & $16.94 \pm 0.61 \mathrm{a}$ \\
\hline $\mathrm{C} 18: 3 \mathrm{n} 3$ & $0.82 \pm 0.02 \mathrm{~b}$ & $0.82 \pm 0.19 b$ & $0.93 \pm 0.04 \mathrm{ab}$ & $1.01 \pm 0.10 \mathrm{a}$ & $0.87 \pm 0.03 \mathrm{ab}$ & $0.89 \pm 0.03 \mathrm{ab}$ & $1.01 \pm 0.06 \mathrm{a}$ \\
\hline C18:3n6 & $0.06 \pm 0.01$ & $0.05 \pm 0.01$ & $0.06 \pm 0.01$ & $0.06 \pm 0.01$ & $0.05 \pm 0.01$ & $0.05 \pm 0.01$ & $0.06 \pm 0.00$ \\
\hline C20:2 & $0.12 \pm 0.02$ & $0.13 \pm 0.01$ & $0.12 \pm 0.03$ & $0.10 \pm 0.02$ & $0.12 \pm 0.03$ & $0.11 \pm 0.02$ & $0.12 \pm 0.01$ \\
\hline $\mathrm{C} 20: 3$ & $0.06 \pm 0.01 \mathrm{~b}$ & $0.06 \pm 0.02 b$ & $0.06 \pm 0.01 \mathrm{~b}$ & $0.08 \pm 0.01 \mathrm{a}$ & $0.06 \pm 0.02 \mathrm{~b}$ & $0.06 \pm 0.00 \mathrm{~b}$ & $0.08 \pm 0.02 \mathrm{a}$ \\
\hline C20:4 & $0.33 \pm 0.00 \mathrm{~b}$ & $0.31 \pm 0.06 \mathrm{~b}$ & $0.31 \pm 0.02 \mathrm{~b}$ & $0.56 \pm 0.18 \mathrm{a}$ & $0.35 \pm 0.04 \mathrm{~b}$ & $0.49 \pm 0.09 \mathrm{a}$ & $0.62 \pm 0.11 \mathrm{a}$ \\
\hline $\mathrm{C} 20: 5$ & $0.03 \pm 0.00$ & $0.03 \pm 0.02$ & $0.02 \pm 0.02$ & $0.04 \pm 0.01$ & $0.03 \pm 0.02$ & $0.03 \pm 0.01$ & $0.03 \pm 0.02$ \\
\hline $\mathrm{C} 22: 6$ & $0.02 \pm 0.02$ & $0.02 \pm 0.02$ & $0.02 \pm 0.02$ & $0.02 \pm 0.02$ & $0.02 \pm 0.02$ & $0.02 \pm 0.02$ & $0.02 \pm 0.02$ \\
\hline TOTAL & $15.33 \pm 0.18 b$ & $15.24 \pm 2.06 \mathrm{~b}$ & $15.82 \pm 0.50 \mathrm{~b}$ & $18.17 \pm 1.38 \mathrm{a}$ & $15.85 \pm 0.86 \mathrm{~b}$ & $17.93 \pm 0.89 \mathrm{a}$ & $18.88 \pm 0.84 \mathrm{a}$ \\
\hline
\end{tabular}

Hasil analisis laboratorium kimia terpadu IPB; B1: beluntas 1 minggu; B2:beluntas 2 minggu; B3:beluntas 3 minggu; K1:kenikir 1 minggu; K2:kenikir 2 minggu; K3:kenikir 3 minggu; angka yang disertai dengan huruf yang berbeda pada baris yang sama menunjukkan berbeda nyata $(\mathrm{P}<0.05)$.

Pada perlakuan B3, K2, dan K3 kandungan ALTJ nyata lebih tinggi dan tidak mudah teroksidasi. Hal ini didukung dengan hasil analisis kadar MDA yang merupakan indikasi kerusakan daging akibat oksidasi lemak yang nyata lebih rendah dibandingkan dengan kontrol. Hal ini menunjukkan bahwa oksidasi ALTJ dapat mempengaruhi kadar MDA pada daging itik. Kandungan antioksidan pada beluntas atau kenikir dapat menghambat ALTJ teroksidasi dengan cara mengubah rantai senyawa menjadi lebih stabil. Menurut Rukmiasih (2011), pemberian antioksidan dapat menghambat kerusakan asam lemak pada daging itik.

\section{Hasil Uji Hedonik Daging Itik yang diberi Pakan Tepung Daun Beluntas atau Kenikir}

Kreteria mutu uji hedonik yang diamati yakni bau, warna, dan tekstur pada daging mentah dan matang disajikan pada Tabel 5. Kreteria mutu uji hedonik daging mentah menunjukkan hasil yang tidak berbeda. Hal ini diduga karena flavor daging mentah masih lemah dan oksidasi juga masih rendah sehingga sulit dibedakan. Menurut Hogan (2002), dalam keadaan mentah daging memiliki flavor yang sangat lemah. Hasil uji hedonik warna dan tekstur pada daging matang juga tidak berbeda. Hal ini diduga karena umur, bangsa, dan jenis kelamin ternak sama sehingga pembentukan mioglobin dan serabut otot pada daging juga sama. Hal ini sejalan dengan pernyataan Soeparno (1994), penentu utama konsentrasi pigmen mioglobin dan tekstur otot pada daging dipengaruhi umur, bangsa, dan jenis kelamin.

Pada kreteria mutu uji hedonik bau menunjukkan skala 3 sampai 4 (agak suka - suka) pada daging mentah, namun pada daging matang menunjukkan skala 1 sampai 
Tabel 5. Uji Hedonik atau Tingkat Kesukaan terhadap Daging Itik Segar dan Matang

\begin{tabular}{lcccccc}
\hline \multirow{2}{*}{ Pelakuan } & \multicolumn{3}{c}{ Daging Mentah (Segar) } & \multicolumn{3}{c}{ Daging Matang } \\
\cline { 2 - 7 } & Bau & Warna & Tekstur & Bau & Warna & Tekstur \\
\hline Kontrol & 3.77 & 4.26 & 4.00 & $1.15 \mathrm{c}$ & 3.36 & 3.36 \\
B1 & 3.79 & 4.23 & 4.01 & $1.24 \mathrm{c}$ & 3.37 & 3.31 \\
B2 & 3.77 & 4.20 & 4.02 & $1.44 \mathrm{~b}$ & 3.34 & 3.39 \\
B3 & 3.79 & 4.25 & 4.04 & $1.64 \mathrm{a}$ & 3.36 & 3.27 \\
K1 & 3.84 & 4.29 & 4.05 & $1.14 \mathrm{c}$ & 3.44 & 3.46 \\
K2 & 3.87 & 4.29 & 4.02 & $1.59 \mathrm{ab}$ & 3.41 & 3.42 \\
K3 & 3.91 & 4.27 & 4.00 & $1.65 \mathrm{a}$ & 3.34 & 3.40 \\
\hline
\end{tabular}

B1: beluntas 1 minggu; B2:beluntas 2 minggu; B3:beluntas 3 minggu; K1:kenikir 1 minggu; K2:kenikir 2 minggu; K3:kenikir 3 minggu; angka yang disertai dengan huruf yang berbeda pada kolom yang sama menunjukkan berbeda nyata $(\mathrm{P}<0.05)$ dengan uji Kruskall-Wallis; Hedonik : 1 sangat tidak suka, 2 tidak suka,

3 agak suka, 4 suka, 5 sangat suka

2 (sangat tidak disukai - tidak suka) (Tabel 5). Hasil ini menunjukkan penurunan skala kesukaan panelis terhadap bau daging itik matang. Hal ini diduga karena selama pemasakan komponen flavor maupun off-flavor pada daging semakin kuat. Menurut Purba (2014), selama proses pemanasan terjadi interaksi antar prekursor-prekursor didalam bahan pangan, khususnya reaksi antara karbohidrat dengan asam amino dan oksidasi lemak. Oksidasi lemak yang tinggi dapat menyebabkan perubahan bau pada daging.

Berdasarkan uji statistik, bau daging matang pada perlakuan B3, K2, dan K3 nyata lebih disukai dibandingkan dengan kontrol (Tabel 5). Kondisi ini diduga karena aktivitas antioksidan pada perlakuan tersebuta lebih tinggi sehingga reaksi oksidasi lebih rendah dan pembentukan off-flavor akibat oksidasi juga lebih sedikit. Menurut Randa (2007), oksidasi lemak yang tinggi pada daging dapat menyebabkan penyimpangan flavor. Pernyataan tersebut diperkuat oleh Kim et al (2006a), kerusakan asam lemak C16:0, C18:1, dan C18:2 akibat oksidasi dapat menimbulkan off-flavor.

\section{KESIMPULAN}

Pemberian beluntas selama 3 minggu menunjukkan efektivitas yang sama dengan pemberian kenikir selama 2 dan 3 minggu. Kandungan antioksidan kenikir nyata lebih cepat dalam melindungi asam lemak dan menurunkan kadar MDA. Kriteria mutu uji hedonik bau daging itik matang masih berada pada skala sangat tidak disukai sampai tidak disukai

\section{DAFTAR PUSTAKA}

Andarwulan, N., R. Batari, D.A. Sandrasari, \& H. Wijaya. 2010. Flavonoid Content and Antioxidant Activity of Vegetables from Indonesia. J. Food Chemistry. 121: 1231-1235.

AOAC. 1984. Official Methods of Analysis of the Association of Official Analytical Chemists. 14thEd. Association of Official Analytical Chemists. Virginia (US): AOAC International. Inc, Arlington.
AOAC. 2005. Analysis of Fatty Acid Metil Ester. Official Method 969.33. New York (US): AOAC International.

Chanwitheesuk, A., A. Teerawutgulrag, \& N. Rakariyatham. 2005. Screening of Antioxidant Activity and Antioxidant Compounds of Some Edible Plants of Thailand. J. Food Chemistry. 92: 491-497.

Conforti, F., G. Statti, D. Uzunov, \& F. Menichini. 2006. Comparative Chemical Composition and Antioxidant Activities of Wild and Cultivated Laurus Nobilis L. Leaves and Foeniculum Vulgare Subsp. Piperitum (Ucria) Coutinho Seeds. J. Bio. and Pharmaceutical. 29 (10): 2056-2064.

Direktorat Jendral Peternakan dan Kesehatan Hewan [Ditjen PKH]. 2019. Statistik Peternakan dan Kesehatan Hewan (Livestock And Animal Health Statistics) 2016. Jakarta. http://ditjennak.pertanian. go.id. [21 Oktober 2017]

Hogan, B. 2002. Putting Punch in Meat Flavor Profiles. Food Product Design: Design Elemen. http:/www. foodproductdesign.com/archive/2002/0702DE.html. [5 Januari 2018]

Juntachote, T., E. Berghofer, S. Siebenhandl, \& F. Bauer. 2007. Antioxidative Effects Of Added Dried Holy Basil and its Ethanolic Extracts on Susceptibility Grounds Pork to Lipid Oxidation. J. Food Chem. 100 : 129-135.

Kim, G. D., J. Y. Jeong, S. H. Moon, Y. H. Hwang, G. - Park, \& S. T. Joo. 2006a. Division of Applied Life Science, Graduate School. Gyeongsang National University. Korea: Jinju, Gyeongnam 660 - 701. pp. $1-3$.

Kim, G. D., J. Y. Jeong, S. H. Moon, Y. H. Hwang, G. B. Park, \& S. T. Joo. 2009b. Effects of Muscle Fibre Type on Meat Characteristics of Chicken and Duck Breast Muscle. Articel: https://www.Researchgate. Net/Publication/237595272

Lestari, D., Rukmiasih, T. Suryati, \& P. S. Hardjosworo. 2017. Performa Itik Lokal (Anas platyrhynchos Javanica) yang diberi Tepung Daun Beluntas atau Kenikir sebagai Sumber Pakan Aditif. JIPTHP. Vol. 5(1) : 34-40.

Matitaputty, P. R. 2012. Peningkatan Produktivitas Karkas Dan Kualitas Daging Itik Melalui Persilangan Antara Itik Cihateup Dengan Itik Alabio. Disertasi. Sekolah Pascasarjana, Institut Pertanian Bogor, Bogor.

Matitaputty, \& P. R, Suryana. 2014. Tinjauan Tentang Performans Itik Cihateup (Anas Platyrhynchos Javanica) sebagai Sumberdaya Genetik Unggas Lokal di Indonesia. J. Wartazoa. 24: 171-178.

Muzani, A., B. Brahmantiyo, C. Sumantri, \& A. Tapyadi. 2005. Pendugaan Jarak Genetik Pada Itik Cihateup, Cirebon dan Mojosari. Jurnal Media Peternakan. 28:109-116.

Navarro, J. M., P. Flores, C. Garrido, \& V. Martinez. 2006. Changes in the Contents of Antioxidant Compounds in Pepper Fruits at Different Ripening Stages, as Affected By Salinity. J. Food Chemistry. 96 : 66-73.

Nurjanah, L. Izzati, \& A. Abdullah. 2011. Aktivitas Antioksidan dan Komponen Bioaktif Kerang Pisau 
(Solen Spp). Jurnal Ilmu Kelautan. 16(3):119-124.

Paini, S. W. 2011. Aktivitas Antioksidan Ekstrak Metanolik Daun Beluntas (Pluchea Indica Less) dan Fraksinya serta Kemampuan Mencegah Warmed Over Flavor pada Daging Itik yang telah dipanaskan. Disertasi. Sekolah Pascasarjana, Institut Pertanian Bogor, Bogor.

Permana, D. N., F. Lajis, A.G. Abas, R. Othman, M. Ahmad, H. Kitajama, \& N. Takayama, Aimi. 2003. Antioksidative Constituents Of Hedotis Diffusa Wild. J. Natural Product Sci. 9 (1): 7-9.

Purba, M. 2014. Pembentukan Flavor Daging Unggas oleh Proses Pemanasan dan Oksidasi Lipida. J. Wartazoa. 24 (3): 109-118.

Rababah, T., N. S. Hettiarachchy, R. Horax, M. J. Cho, B. Davis, \& J. Dickson. 2006. Thiobarbituric Acid Reactive Substances and Volatile Compounds in Chicken Breast Meat Infused with Plant Extracts and Subjected to Electron Beam Irradiation. J. Poult. Sci. 85 (6): 1107-1113.

Randa, S. Y. 2007. Bau Daging dan Performa Itik Akibat Pengaruh Perbedaan Galur dan Jenis Lemak serta Kombinasi Komposisi Antioksidan (Vitamin A, C, Dan E) dalam Pakan Disertasi. Sekolah Pascasarjana, Institut Pertanian Bogor, Bogor.

Rukmiasih. 2011. Penurunan Bau Amis (Off-Odor) Daging Itik Lokal dengan Pemberian Tepung Daun Beluntas (Plucheaindica L.) dalam Pakan dan Dampaknya Terhadap Performa. Disertasi. Sekolah Pascasarjana, Institut Pertanian Bogor, Bogor.

Sacchetti, G., C. D. Mattia, P. Pittia, \& G. Martino. 2008. Application of a Radical Scavenging Activity Test to Measure the Total Antioxidant Activity of Poultry Meat. J. Meat Science. 80 : 1081-1085.

Soeparno. 1994. Ilmu dan Teknologi Daging. Fakultas Peternakan: Universitas Gadjah Mada. Edisi ke-2. Gadjah Mada University Press, Yogyakarta.

Sorensen, G., \& S. S Jorgensen. 1996. a Critical Examination of Some Experimental Variables in the 2-Thiobarbituric Acid (TBA) Test for Lipid Oxidation in Meat Products. J. Zeitschrift fur Lebensmittel Untersuchung und Forschung. 202: 205-210.
Sinurat, A. P. 2000. Penyusunan Ransum Ayam Buras dan Itik. Pelatihan Proyek Pengembangan Agribisnis Peternakan. Dinas Peternakan DKI Jakarta, Jakarta.

Steel, G. R., \& H. J. Torrie. 1995. Prinsip dan Prosedur Statistika: Suatu Pendekatan Biometrik. Edisi ke-2. Terjemahan B. Sumantri. Gramedia Pustaka Utama, Jakarta.

Sudarmadji, S. 2003. Mikrobiologi Pangan. PAU Pangan dan Gizi UGM. Gadjah Mada University Press, Yogyakarta.

Tamat, S. R., T. Wikanta, \& L. S. Maulina. 2007. Aktivitas Antioksidan dan Toksisitas Senyawa Bioaktif dari Ekstrak Rumput Laut Hijau Ulva Reticulata Forskal. Jurnal Ilmu Kefarmasian Indonesia. 5(1): 31-36.

Tangkanakul, P., P. Auttaviboonkul, B. Niyomwit, N. Lowvitoon, P. Charoenthamawat, \& G. Trakoontivakorn. 2009. Antioxidant Capacity, Total Phenolic Content and Nutritional Composition of Asian Foods After Thermal Processing. J. International Food Research. 16: 571-580

Valentao, P., P. Trindade, D. Gomes, P. G. Pinho, T. Mouga, \& P. B. Andrade. 2010. Codium Tomentosum and Plocamium Cartilagineum: Chemistry And Antioxidant Potential. Food Chemistry. 119 : 13591368.

Wulandari, W.A., P. S. Hardjosworo, \& Gunawan. 2005. Kajian Karakteristik Biologis Itik Cihateup dari Kabupaten Tasikmalaya dan Garut. Seminar Nasional Teknologi Peternakan Dan Veteriner. Pusat Penelitian dan Pengembangan Peternakan. Bogor.

Yoon, J. H., M.S Lee, \& J. H. Kang. 2010. Reaction of Ferritin with Hydrogen Peroxide Induces Lipid Peroxidation. J. Biochemistry and Molecular Biology (Bmb Reports) : 219224.

Zhao, X., E. E. Carey, J. E. Young, W. Wang, \& T. Iwamoto. 2007. Influence of Organic Fertilization, High Tunnel Environment, and Postharvest Storage on Phenolic Compounds in Lettuce. J. Hort science. 42(1): 71-76. 